\title{
(DES) ENCONTROS DE UMA ETNOGRAFIA MULTISSITUADA EM REGIÕES URBANAS DE MARGINALIDADE AVANÇADA NO BRASIL E EM PORTUGAL
}

\author{
Ana Patrícia Barbosa ${ }^{1}$ \\ Sofia Sousa ${ }^{2}$ \\ Paula Guerra ${ }^{3}$ \\ Ana Luiza Carvalho da Rocha ${ }^{4}$
}

\section{Introdução}

O presente artigo apresenta uma etnografia multissituada de duas regiões: a Grande Cruzeiro, em Porto Alegre/RS, no Brasil e o Bairro do Cerco ${ }^{5}$, no Distrito do Porto, em Portugal, onde procuramos analisar as formas do viver urbano das camadas mais pobres da população nos diferentes contextos contemporâneos que estabelecem conflitos e arranjos que dimensionam a vida social nas modernas sociedades complexas (Velho, $1979 ; 1989 ; 2004)$, em especial no que se refere aos novos arranjos territoriais das grandes metrópoles brasileiras, dado o contexto de transformações socioespaciais, reconfigurando espaços e grupos sociais.

O estudo aqui apresentado orienta-se pelo argumento da produção de territorialidades, direcionando o seu foco para experiências urbanas possíveis, tal como proposto pro David Harvey (1989) no que tange a forma como as desigualdades sociais incidem sobre as dinâmicas das cidades, destacando a existência de uma geopolítica das populações urbanas, a partir de suas possibilidades de controlo de fontes de poder social, tais quais tempo, espaço e dinheiro na metrópole. Para o presente estudo, cabe ter claro que os efeitos dessas desigualdades consolidam uma mobilidade urbana das populações das camadas mais pobres da população, mobilidade esta repleta de

\footnotetext{
${ }^{1}$ Universidade Luterana do Brasil, Brasil.

${ }^{2}$ Faculdade de Letras da Universidade do Porto, Portugal. Email: ssousa@,letras.up.pt ORCID id: https://orcid.org/0000-0002-3504-5394

${ }^{3}$ Faculdade de Letras da Universidade do Porto e Instituto Sociologia Universidade do Porto, Portugal. Email: pguerra@letras.up.pt ORCID id : https://orcid.org/0000-0003-2377-8045

${ }^{4}$ Universidade Feevale e Universidade Federal do Rio Grande do Sul, Brasil. Email: miriablis@gmail.com ORCID id: https://orcid.org/0000-0002-2294-5932

${ }^{5}$ Este artigo inscreve-se no desenvolvimento do Projeto de Investigação "CANVAS - Towards Safer and Attractive Cities: Crime and Violence Prevention through Smart Planning and Artistic Resistance" (referência Ref. ${ }^{a}$ POCI-01-0145-FEDER-030748).
} 
simbolismos, enraizamentos e processos de territorialização, desterritorialização e reterritorialização (Haesbaert, 2004, 2005).

Nossa preocupação investigativa é resgatar as histórias, as imagens e memórias das duas regiões estudadas, apresentando-as como objetos de contínua construção, por meio de uma sobreposição de camadas de tempo, de sujeitos e grupos sociais, que oferece possibilidades de duração no tempo frente às (im)possibilidades cotidianas que se expressam no cenário urbano. Trata-se de regiões não só com suas mazelas, mas também com os arranjos que os moradores fazem para viver nela (ou sobreviver), sem negar a realidade nem procurar amenizar suas consequências (Magnani, 1996).

Compreender a constituição da região a Grande Cruzeiro e do Bairro do Cerco, sob essa perspetiva, é realizar uma "etnografia da duração", nos moldes propostos por Ana Luiza Carvalho da Rocha e Cornelia Eckert (2005), na qual os sujeitos, os grupos sociais e os territórios constituem conjuntamente seus processos no tempo. Percorrer os meandros das histórias e memórias de uma cidade e seus territórios é conhecer arranjos temporais diversos, é apreender "as formas múltiplas do viver a cidade, das experiências geracionais de continuidade e descontinuidade nos ritmos citadinos de seus moradores" (Rocha \& Eckert, 2001: 109).

A intenção, ao reconstruir a formação inicial da Grande Cruzeiro e do Bairro do Cerco é abrir uma colcha de lembranças que permita compreender as afrontas do tempo presentes na forma como a cidade concebe as regiões, bem como a insistência de seus moradores em perdurar no tempo e constituir suas territorialidades, em meio a permanente produção de invisibilidades e impossibilidades cotidianas que a cidade produz em relação a estas regiões.

O objetivo primordial desta investigação prende-se com o entendimento dos moradores das camadas mais pobres da população urbana de Porto Alegre/RS/Brasil e do Distrito do Porto/Portugal. Visto que no caso de Portugal, o Bairro do Cerco apesar de pertence à cidade do Porto, este situa-se numa das freguesias mais estigmatizadas e perféricas da cidade, nomeadamente a freguesia de Campanhã. Alvo de múltiplos processos de exclusão social, segregação urbana e social, mas também laboratório de diversas intervenções políticas, sociais e culturais (Guerra, 2002). Em contrapartida, a Grande Cruzeiro, lócus da pesquisa realizada no Brasil, é considerada uma das mais populosas favelas pertencente à cidade de Porto Alegre, capital do estado do Rio Grande do Sul. Trata-se de uma região caracterizada por uma grande concentração de sub- 
habitações e com múltiplas carências, que revela, em sua complexidade, a desigual distribuição e consumo de equipamentos urbanos, bem como aspectos das condições de existência dos que ali residem (Barbosa, 2017).

A estas questões soma-se a nossa preocupação as transformações mais amplas das sociedades locais, decorrentes dos processos de modernização/urbanização e de ampliação da vida e das relações da cidade com uma série de outros lugares. Neste sentido, buscamos reconstruir a formação inicial da Grande Cruzeiro e do Bairro do Cerco, compreendendo as regiões nas suas trajetórias históricas. Tal entendimento irá proporcionar-nos uma visão ampla e profunda sobre contextos e condições de enfrentamento, bem como de resistência face aos problemas sociais de que os mesmos iam sendo alvo.

\section{De Porto Alegre ao Porto: uma breve viagem sobre descontinuidades e pontos de interseção}

Figura 1 Delimitação territorial do Bairro do Cerco do Porto, em Portugal (à esquerda) e a vista parcial da Grande Cruzeiro, em 2017 (à direita)
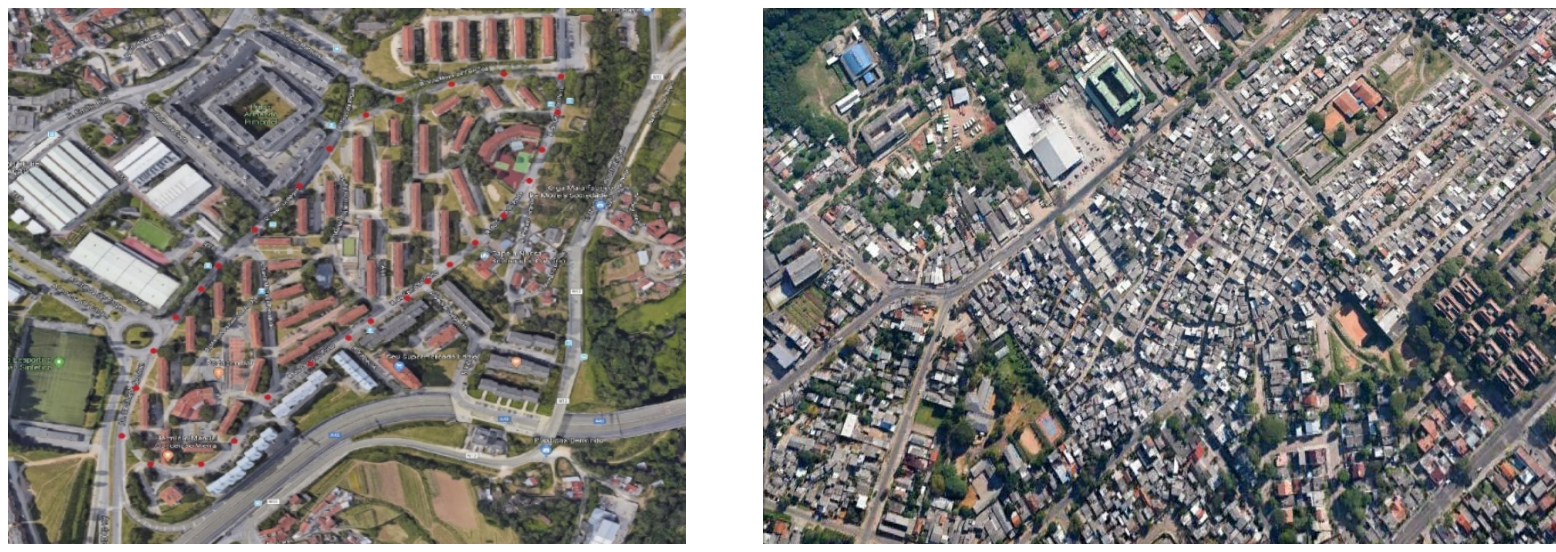

Fonte: Google Earth Pro, 2020; Google Maps, 2017.

Em Portugal, a década de 90 foi decisiva nos processos de recomposição social e espacial do tecido urbano portuense, pautando-se por uma reestruturação acentuada na Zona Oriental da Cidade, nomeadamente na Freguesia de Campanhã - local onde se insere o nosso objeto de estudo. Ora, foi nos anos 90 que assistimos a uma tomada de consciência política sobre esta área urbana, que até então tinha sido esquecida, tendo tal aspeto contribuído para a cimentação de fenômenos sociais desigualitários e de 
processos de exclusão. Estes dois fatores, aliados a dinâmicas mais recentes como as crises e a recessão econômica, podem ser um fator explicativo para o fracasso de todas as medidas que têm vindo a serem implementadas nesse espaço.

Surgem - no âmago dessas intervenções dos anos 90 - estratégias para o desenvolvimento desse espaço, cimentadas na requalificação e na integração do mesmo no espaço urbano portuense - apesar de ainda atualmente se denotar um profundo afastamento não só espacial como também social, face ao centro da cidade - , procurando uma mudança de rumo para o local (Guerra, 2002, 2012). Além das descontinuidades urbanas e dos processos de desterritorialização (Haesbaert, 2004, 2005), a zona oriental da cidade do Porto pautava-se pela concentração de uma população relativamente homogênea no âmbito da sua privação de recursos socialmente valorizados, tais como a cultura ou outras práticas culturais. Estas preocupações políticas refletem-se na elaboração do Plano Estratégico para o Vale de Campanhã, solidificado com o Plano de Intervenção URBAN I e II (Guerra, 2002), que assume vários objetivos prioritários ligados ao planejamento urbano e à intervenção social (Sousa, 2018).

A localização periférica deste bairro ${ }^{6}$, bem como a ausência de investimentos nesta freguesia durante décadas, contribuiu para a existência de uma situação atual de desqualificação urbana e degradação habitacional notória. A questão da habitação é essencial nesta freguesia, sendo frequentemente identificada como um problema basilar que acentua outras situações problemáticas. Em alguns casos como o Bairro do Cerco, o estado de conservação dos edifícios e dos espaços é/era manifestamente degradado. Este emergiu no século XX, tendo sido inaugurado em 1963, como um bairro social destinado a albergar a população oriunda das ilhas insalubres ${ }^{7}$ e, desde a sua inauguração até aos dias atuais que o mesmo é tido como um bairro problemático, alvo de múltiplas intervenções políticas, sociais e culturais, e que se assume como um espaço de medo e de incertezas. Muitos ainda o veem como um território de drogas, onde impera o estigma, a pobreza e a exclusão social.

\footnotetext{
${ }^{6}$ Esta designação de bairro corresponde - no contexto português - a todas as tipologias de habitação, de caráter social, isto é, habitações essas em que os seus residentes contam com algum tipo de apoio por parte das Câmaras Municipais, frequentemente com valores de renda, água e luz mais baixos. São tipologias habitacionais destinadas a indivíduos que possuem dificuldades financeiras ou que necessitam de serem realojados. A designação de bairro, paulatinamente assumiu uma conotação negativa, estando o mesmo associado à criminalidade, aos conflitos, a fracas condições habitacionais, à exclusão social e outros tipos de carências sociais, econômicas, políticas e culturais.

${ }^{7}$ Outra modalidade habitacional característica da cidade do Porto, muito comum na época junto das camadas operárias (Queirós, 2014).
} 
Estas representações sobre o bairro são tão mais evidentes quando se assume que este é um dos bairros sociais que mais população alberga, no total dos bairros sociais do Porto. Inicialmente, o Bairro do Cerco era constituído por 32 blocos habitacionais, contudo devido às fragilidades econômicas de um elevado segmento populacional, em 1991 foi feita uma ampliação, passando para os 34 blocos habitacionais atuais. Acomoda, sensivelmente 2087 pessoas, e é o segundo maior bairro no que diz respeito ao número de habitações. Sempre se pautou pela fragilidade habitacional, visto que apenas recentemente - em 2019 - fizeram obras de manutenção às fachadas dos blocos habitacionais. Algumas intervenções já tinham vindo a ser feitas, como por exemplo, pintarem as fachadas dos blocos e decorá-las com desenhos, alterar a própria cor da fachada (do branco original para um rosa velho) e, nesta última intervenção procuram conferir-lhes um aspeto arquitetônico moderno, reconfigurando-as (a cor passa a ser o azul e as varandas brancas).

Previamente a esta intervenção, as entradas dos blocos habitacionais apresentavam um aspeto similar ao de grades de prisões, prevalecia a instabilidade estrutural nas varandas e a umidade no interior das casas, associada à pequena dimensão da maior parte delas. Inúmeras alterações foram feitas, mas parece que nada surte efeito. Pintam-se as fachadas hoje, e amanhã surgem graffites e pichações. Também os seus moradores - a grande maioria - já foi objeto de sucessivos processos de realojamento, sem terem em linha de conta - por parte das entidades responsáveis - a sua integração social, física e cultural, especialmente no caso da comunidade cigana, extremamente representativa dentro do Bairro do Cerco e na maioria dos bairros sociais do Porto. Estes elementos conjugados configuram o bairro como uma zona de forte visibilidade de problemas sociais, intensificando o mapeamento mental da cidade e assumindo-o como um espaço desviante e perigoso.

Figura 2 Evolução das fachadas do Bairro do Cerco do Porto. A primeira foto quando da sua construção, em 1963. Na segunda foto (lado direito), as fachadas em 2002
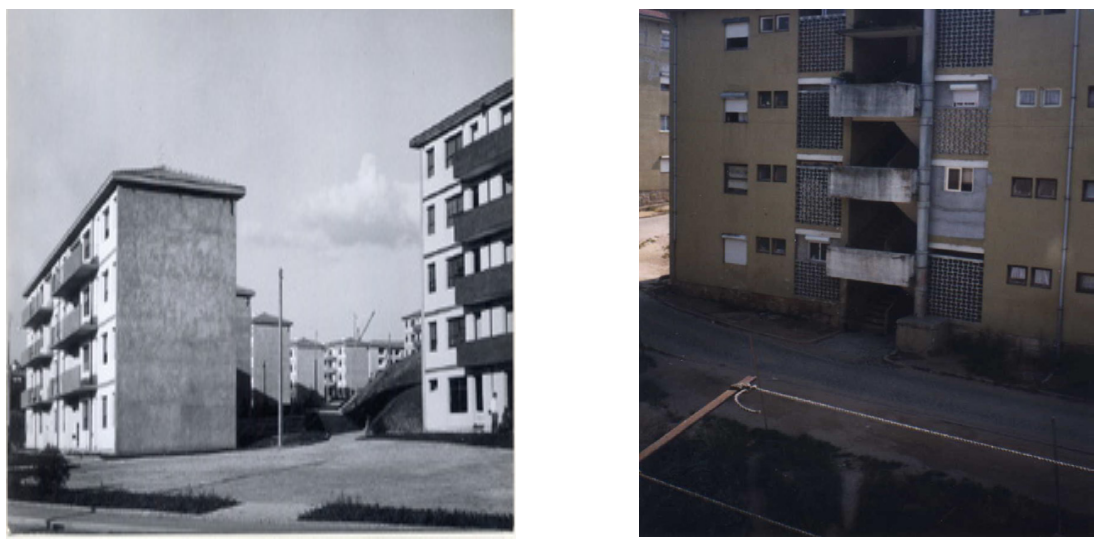

Iluminuras, Porto Alegre, v. 21, n. 54, p. 447-477, setembro, 2020. 
Fonte: Câmara Municipal do Porto ${ }^{8}$; Guerra (2002).

Figura 3 Evolução das fachadas do Bairro do Cerco do Porto. Do lado esquerdo temos as fachadas do Bairro em 2018 e do lado direito, em 2019/2020 o resultado final com a última reabilitação

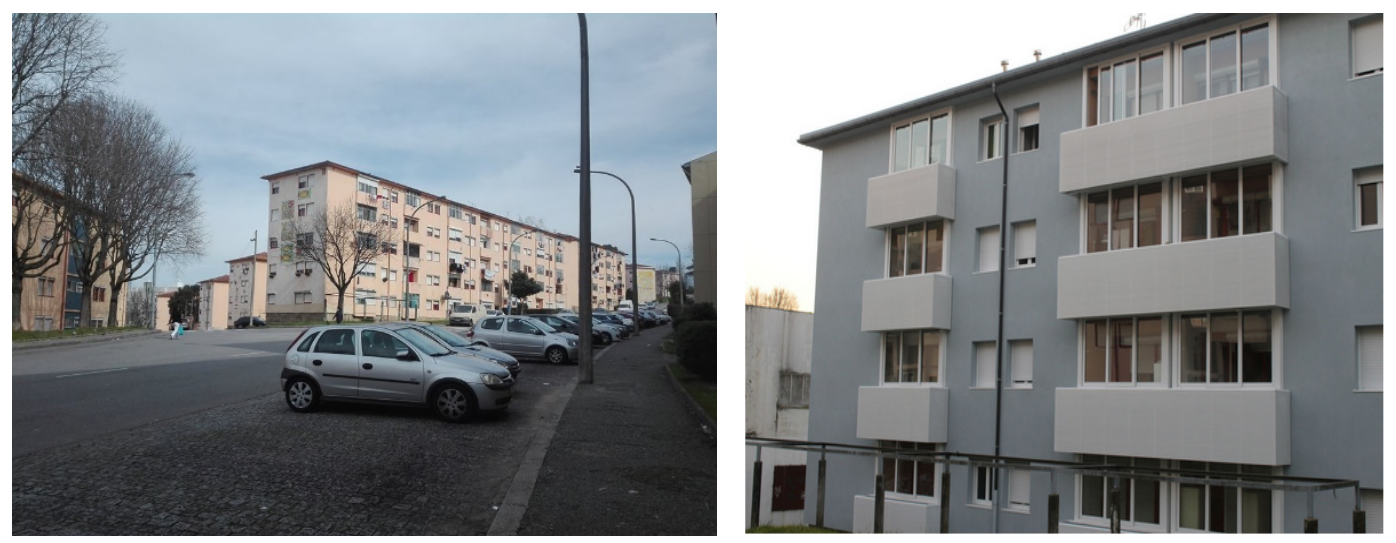

Fonte: Sousa (2018); Rodrigues e Almeida (2019/2020).

Atendendo a estas características sociais e territoriais, consideramos importante entender os conjuntos de relações que se inscrevem neste espaço. $\mathrm{O}$ bairro é um local privilegiado de ação. Nesse sentido, destacamos os contributos de António Firmino da Costa (1984), uma vez que pretendemos perceber o Bairro do Cerco e a região da Grande Cruzeiro como espaços vivenciais que são pautados por um conjunto de práticas estruturais, de lógicas, de racionalidades, de códigos e simbologias, que o organizam e compõem como uma forma espacial específica, que é simultaneamente estruturada e estruturante (Guerra, 2012). As construções sociais dos espaços refletem-se nas práticas sociais, que por sua vez são ordenadas no tempo e no espaço, logo o espaço é um elemento material que organiza essas combinações (Rémy, 1974).

Paralelamente ao Bairro do Cerco, prosseguimos a nossa viagem teóricoempírica rumo ao Brasil, mais especificamente a região da Grande Cruzeiro, uma das mais populosas favelas ${ }^{9}$, composta por um conglomerado de 60 vilas ${ }^{10}$, localizada

\footnotetext{
${ }^{8}$ Disponível em: https://infomedia.atavist.com/bairro-do-cerco\#chapter-4564647

${ }^{9}$ Favela é compreendida neste estudo como área de habitações irregulares construídas, sem arruamentos, sem plano urbano, sem esgoto, sem água, sem luz. Dessa precariedade urbana, resultado da pobreza de seus habitantes e do descaso do poder público, surgiram as imagens que fizeram da favela o lugar da carência, da falta, do vazio a ser preenchido pelos sentimentos humanitários, do perigo a ser erradicado pelas estratégias políticas que fizeram do favelado um bode expiatório dos problemas a cidade, o "outro", distinto do morador civilizado da primeira metrópole que o Brasil teve (Zaluar, 1999).

${ }^{10}$ A utilização do termo Vila serve para caracterizar as favelas no sul do país e tem origem no termo "vila operária", utilizado "para nomear um grupo de moradias destinadas a operários de um mesmo
} 
apenas a $6 \mathrm{~km}$ do centro da cidade de Porto Alegre, capital do estado mais meridional do Brasil, o Rio Grande do Sul, e que figura em sexto lugar entre as dez melhores cidades para se viver no Brasil ${ }^{11}$. No ano de 2010, recebeu destaque pela Organização das Nações Unidas (ONU) como a metrópole número um em qualidade de vida, possuindo um dos quarenta modelos de gestão pública democrática pelo seu Orçamento Participativo $^{12}$ (OP) e por ter o melhor índice de Desenvolvimento Humano (IDH) entre as metrópoles nacionais. É sede da maior concentração urbana da Região Sul, e a quinta cidade mais populosa do país, com uma população em torno de 1.400 .000 (um milhão e quatrocentos mil) habitantes.

Figura 3 - Diagrama localização Brasil, Rio Grande do Sul e Porto Alegre (à esqueda) e a localização da freguesia de Campanhã (assinalada com traços azuis) em relação do Concelho do Porto
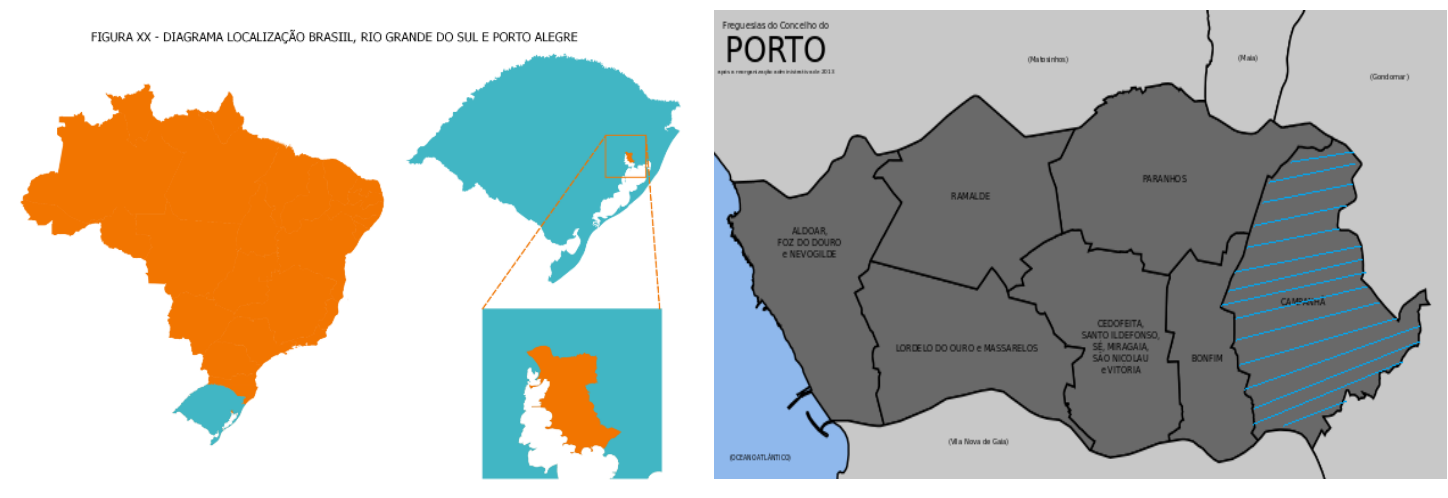

Fonte: Barbosa (2017); Google.

Porto Alegre experimentou um crescimento vertiginoso e desordenado da população urbana, especialmente a partir da segunda metade do século XX, quando as

empreendimento fabril...", mas que em seguida "seria estendido para designar grupos de casas modestas semelhantes produzidas por outros agentes” (Correia, 2001:84, Apud Eckert e Lord, 2015).

${ }^{11}$ Pochmann, M.; Amorim, R. (Orgs). Atlas da exclusão social no Brasil. São Paulo: Cortez, 2003.

12 O Orçamento Participativo foi implantado pela Prefeitura de Porto Alegre no ano de 1989. A cidade de Porto Alegre foi dividida em 17 Regiões e seis Temáticas. Até o Ciclo do OP 2006/2007, a cidade comportava 16 regiões. A partir do Ciclo 2007/2008, a Região 01 foi dividida, oportunizando a criação da Região 17. Todo cidadão pode participar das discussões do OP, na sua Região e nas Temáticas. Nas Regiões, discutem-se e definem-se os investimentos e serviços específicos das Regiões; nas Temáticas, discutem-se e definem-se as diretrizes, os investimentos e os serviços para toda a cidade, isto é, obras estruturais e grandes projetos. Fonte: PORTO ALEGRE. Prefeitura Municipal. Orçamento Participativo. Disponível em<http://www2.portoalegre.rs.gov.br/op/Z. Acesso em 01 de set. 2017. 
grandes cidades brasileiras passaram por profundas transformações advindas do processo de urbanização. Segundo dados do Instituto Brasileiro de Geografia e Estatística (IBGE, 2010), a população urbana brasileira, em 1945, era de 25\%, e, em 2010, chegou a 84\%, ocasionando, em um curto espaço de tempo, uma mudança brusca na forma de uso e ocupação do solo urbano, sem planejamento adequado para receber tal demanda, criando condições para que, paralelo ao desenvolvimento das áreas centrais das cidades, começasse o afastamento da população das camadas mais pobres para zonas de infraestrutura mínima ou zero (Ávila \& Araújo, 2006).

Atualmente, 11,7 milhões da população do Brasil vive em favelas, o que significa $6 \%$ da população brasileira. Esse número representa um pouco mais que a população inteira de Portugal ou mais de três vezes a do Uruguai. Se compusessem um estado, as favelas seriam o quinto mais populoso da federação do Brasil (Meirelles \& Athayde, 2014). No que se refere ao Estado do Rio Grande do Sul, o IBGE (2010) aponta que, em dez anos, o Estado, ganhou 68,2 mil favelados, e, que de 2000 até 2010, o número de favelas teve um crescimento de $29,8 \%$, o que representa mais que o dobro do crescimento da população nesse mesmo período, que foi de $12,3 \%$. Dados do Censo do Instituto Brasileiro de Geografia (IBGE), de $2010^{\mathbf{1 3}}$ demonstram que no interior da cidade de Porto Alegre existem duas grandes concentrações de baixa renda e baixa empregabilidade, sendo a Grande Cruzeiro uma delas. Sua população estimada é de 200.000 mil habitantes, distribuídos numa área de 200 hectares. Estimando-se que a população da cidade de Porto Alegre/RS gira em torno de 1.400 .000 habitantes, observa-se uma grande concentração de moradores na região da Grande Cruzeiro, que perfaz cerca de $15 \%$ da população da cidade, sendo quase a metade dela constituída por crianças e jovens. Trata-se de uma área com densa ocupação das encostas dos morros, tornando-se um grave problema geológico, o que a classifica como área de risco. Além disto, a sua topografia, por ser muito parecida com as favelas da cidade do Rio de Janeiro, é uma das características que pode facilitar a ação do tráfico de drogas.

13 Fonte: IBGE, 2010. Censo Demográfico de 2010. Fundação Instituto Brasileiro de Geografia e Estatística, dados referentes ao município de Porto Alegre, fornecidos em meio eletrônico. 
Figura 4 Evolução das ocupações na região da Grande Cruzeiro. A primeira foto (canto superior esquerdo), vista da Região nos anos 1950. Na segunda foto (canto superior direito) nos anos 1980. A terceira fotografia o canto inferior esquerdo, anos 1990 e, por fim, a última fotografia em 2019
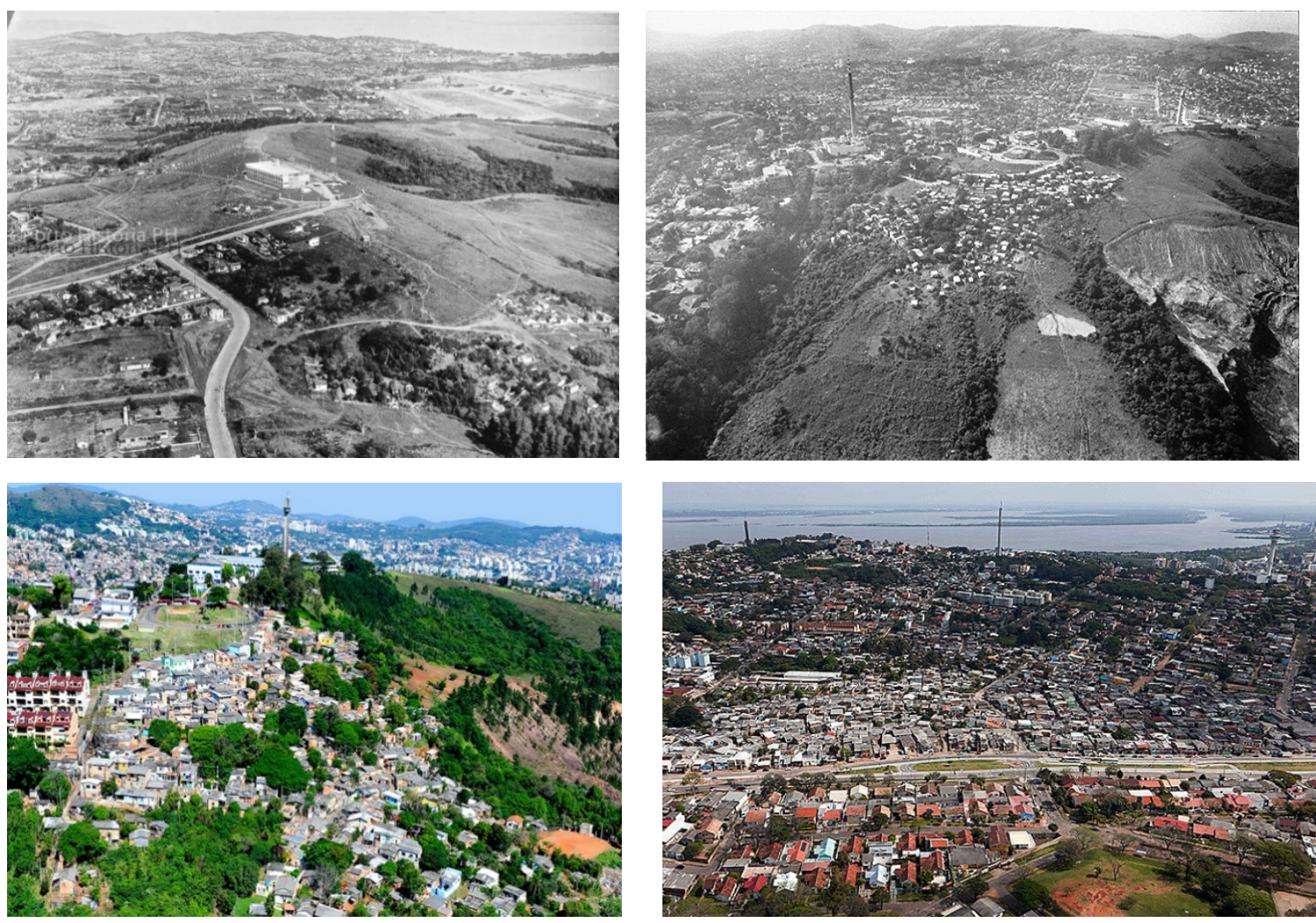

Fonte: Google Maps.

A ocupação e organização do território da Grande Cruzeiro acompanha os ritmos temporais da cidade, num contexto onde diferentes gerações construíram suas práticas e identidades nos espaços então disponíveis (Ávila, 2006). O início da ocupação dessa Região, no final dos anos 1950 e durante os anos 1960, ocorreu num momento de profundas mudanças estruturais na cidade de Porto Alegre, dada a complexificação do espaço urbano e da vida social, pela modernização e industrialização. A produção e organização da Grande Cruzeiro é resultado desse processo histórico de urbanização que a cidade de cidade de Porto Alegre passou nos últimos anos, produzindo uma cidade bem mais complexa em relação à distribuição das pessoas e que reflete a complexidade do processo da urbanização brasileira. Começou a desenvolver-se a partir da segunda metade do século XX, com a chegada de mais ou menos cem famílias, em sua grande maioria vindas de outras localidades da cidade e que foram atraindo outras 
pessoas, dando início às primeiras ocupações na Região.

É importante ressaltar que o surgimento da Grande Cruzeiro ocorreu devido às condições de pobreza de seus ocupantes. Constantemente a Grande Cruzeiro é retratada como uma Região "perigosa", um território valorado negativamente no contexto urbano da cidade de Porto Alegre. Há uma significativa peculiaridade da cidade em relação à Região, que é associá-la à violência e marginalidade. Ao reafirmar a territorialização da pobreza historicamente promovida nesses territórios, se reforça ainda mais as configurações sociais estigmatizantes que pesam sobre eles. Morar na Grande Cruzeiro ou no Bairro do Cerco significa lidar com o preconceito. No caso do Bairro do Cerco, podemos ainda afirmar que mais do que enfrentar processos de hetero-exclusão, as populações residentes do bairro, mais concretamente as mulheres, evidenciam perspectivas de auto-exclusão. Uma vez que os discursos estigmatizantes e discriminatórios possuem um longo legado e, ainda mais, devido à falta de intervenções sociais e políticas naquele local, aliados aos conteúdos dos meios de comunicação social, os próprios moradores do Bairro do Cerco interiorizam esses mesmos discursos e percepções. Estamos assim perante um processo de exteriorização da interioridade, mas também verificamos marcadores que denotam a inteorização da exterioridade (Bourdieu, 1986).

Não se trata de negar que na Grande Cruzeiro, assim como no Bairro do Cerco, não se tenha problemas de criminalidade, mas sim, refletir que esse não deveria ser o foco das atenções dos governos e da sociedade em geral. Neste sentido, os meios de comunicação social parecem desempenhar um papel essencial na construção de um imaginário que apela e incentiva a proliferação de discursos estigmatizantes sobre as populações residentes nesses locais/contextos, enfatizando - uma vez mais - a heteroexclusão. Há uma tendência em tornar visível apenas a esfera da criminalização da pobreza e da marginalidade territorial, como parte explicativa do desregramento social, moral e jurídico a que se encontram submetidos os moradores de periferias, afastandose progressivamente, em alguns aspetos, de uma discussão sobre a precarização dos serviços e equipamentos públicos, na defesa e garantia de direitos à população que vive nas periferias urbanas das grandes metrópoles (Barbosa, 2017), como em Porto Alegre, no Brasil ou no Porto, em Portugal.

Se por um lado, a dimensão segregativa dos moradores da cidade em relação às pessoas que vivem na Grande Cruzeiro e no Bairro do Cerco revela a dimensão da 
exclusão social que se desenha na cidade, por outro lado, pode ser a chave explicativa da solidariedade e da união das comunidades por melhorias nas suas condições de vida. A consolidação desse sentimento solidário, que se reflete frequentemente em relações de vizinhança duradoura e profícuas, como sistema simbólico dos moradores, é o resultado de um longo período em que as pessoas precisaram perpetuar práticas que lhes conferem formas de resistir e de justificarem a sua permanência em territórios marcados e vistos como espaços diferenciados e distantes da cidade, repletos de incertezas e que são analisados como um lócus de exclusão social que criam no imaginário social (Pesavento, 1995), através das suas arquiteturas, dos seus modos de vida que acabam por dar origem a identidades e a formas de habitar e usufruir do espaço urbano. É através destas representações, da atribuição de significados e simbologias, bem como através dos modos de resistência que os espaços passam a ser vistos como lugares, inserindo-os num processo de construção social mais abrangente (Norberg-Schulz, 1974).

Certamente os seus moradores carregam consigo o sentido de território construído. Na sua dimensão material, revela-se concreta e palpável e, na sua dimensão simbólica, constitui-se a partir de manifestações identitárias de apropriação e de pertença, o que pode ser evidenciado tanto na Grande Cruzeiro como no Bairro do Cerco, conforme apresentaremos a seguir.

\section{Do Bairro à Favela: mídia, apropriações e identidades}

Ao nos propormos investigar um campo de estudos que tem sido amplamente debatido, a produção e apropriação do espaço urbano pelas camadas mais pobres da população, foi preciso ir além de interpretações dicotômicas da cidade. Tomamos como pressuposto entendê-la de forma indissociável da apropriação que faz desses espaços, a partir de processos históricos construídos por atores sociais reais, numa multiplicidade de relações, sob condições e contextos diversos e através de práticas cotidianas no/com o espaço urbano ${ }^{14}$.

Esta aparente contradição de imagens da cidade, onde se acomodam diferentes formas do viver urbanos não pode ser analisada numa relação dicotômica de centro/periferia, mas sim como a possibilidade de refletir sobre a complexidade dos

\footnotetext{
14 Estamos nos referindo aqui aos estudos de Teresa Caldeira (1984, 2000), José Guilherme Cantor Magnani (2007,2012), Alba Zaluar (1985, 1998, 1999).
} 
arranjos sociais (Rocha, 1995) no meio urbano e das formas da vida social (Simmel, 1987) que as práticas cotidianas dos habitantes das cidades conformam ao longo do tempo. Neste sentido, a discussão sobre periferia, apresentada neste estudo, se dá numa perspectiva antropológica (Caldeira; 1984; Frúgoli, 2005; 2007; Zaluar, 1985; 1998; 1999), no intuito de compreender um conjunto de produções simbólicas e materiais, por meio do qual se organizam formas de sociabilidade, modos de sentir e pensar o mundo, valores, identidade, práticas sociais e comportamentos coletivos e que caracteriza o estilo de vida dos membros das classes populares.

Conforme Eckert e Rocha (2001: 109) "a cidade e suas possibilidades interpretativas derivam de sua condição de unidade de ação para uma comunidade urbana, uma vez que ela é, ao mesmo tempo, em múltiplos planos, expressão autoral de seus habitantes". Revela o esforço de um corpo coletivo que busca reestabelecer sua possibilidade de existência no tempo (Rocha, 1995). Sob essa perspectiva, buscamos olhar para a cidade real que abriga uma gama complexa de visões de mundo e campos de significados (Velho, 2004), com tramas em constante transformação, revelando continuidades e rupturas frente às dinâmicas socioespaciais. Significa compreender a cidade, suas favelas e periferias, não apenas como conceitos, mas também como campo de práticas constituídas tanto através do diálogo permanente entre o passado e o presente, quanto na justaposição das dimensões qualitativamente heterogêneas de espaço e tempo (De Certeau, 2012).

A Grande Cruzeiro, assim como o Bairro do Cerco são territórios marcados por um histórico de sofrimento e luta. Essa perspectiva não é só evidenciada pelo que foi produzido até hoje a respeito das regiões, mas principalmente pode ser percebido pelas memórias de quem lá habita, por meio de sentimentos que atravessam diferentes temporalidades e durações. A Grande Cruzeiro e o Bairro do Cerco, como uma configuração social, existem em conexão com os sentidos produzidos pelos seus moradores. O que afirmamos é que ambas as regiões existem como territórios pelas práticas, pela memória social, pelos relatos produzidos dos seus moradores para fazerem a vida diante da intensificação do processo de urbanização da cidade, entrecruzando os territórios da precariedade e vulnerabilidades que marcam as suas vidas (NorbergSchulz, 1974).

Em paralelo aos contatos que realizamos durante as pesquisas na Grande Cruzeiro e no Bairro do Cerco recuperamos as notícias de jornais na busca por 
compreender os fios que vão tecendo os olhares em torno destes dois territórios. Metodologicamente procuramos localizar os casos que levavam a Grande Cruzeiro e o Bairro do Cerco aos jornais transformando-os em notícias ao longo do percurso das pesquisa, nos perguntando: qual o sentido dessas notícias? Quem autorizou essas falas? Como foram produzidas? Estas são algumas das interrogações que guiaram a nossa abordagem analítica.

Primeiramente, e indo ao encontro de alguns tópicos que já fomos analisando neste texto, quer o Cerco quer a Grande Cruzeiro são encarados como espaços pautados pela violência e pela criminalidade. Para o caso concreto do Bairro do Cerco, durante o nosso processo de investigação, consideramos relevante perceber quais eram as temáticas e as notícias que eram feitas sobre aquele espaço. Como destacamos inicialmente, o bairro já foi alvo de diversas intervenções políticas, e além do URBAN, aquele que lhe conferiu um maior destaque foi o programa Cultura em Expansão ${ }^{15}$, que teve a sua primeira edição no Bairro do Cerco do Porto, com a criação do projeto musical OUPA! Cerco. Assim, e tendo em mente as entrevistas exploratórias e as conversas informais com os membros do OUPA! Cerco, consideramos que os meios de comunicação social seriam a ponte que deveríamos atravessar para estebelecer uma aproximação inicial ao bairro. Para o efeito, focamo-nos apenas no Jornal Público ${ }^{16}$, tendo sido feito um levantamento de todas as notícias que falassem do Bairro do Cerco, independentemente do conteúdo - entre 2012 e 2017, perfazendo um total de cinquenta e sete notícias - que foram posteriormente categorizadas e alvo de análise de conteúdo. Dada a natureza deste artigo e da vontade de estabelecer uma análise etnográfica multissituada (Marcus, 1998) que é proposta, tentaremos sistematizar a informação, daí que nos iremos focar apenas na análises dos discursos mediáticos, como um meio de compreensão das representações face aos habitantes desses locais, com o intuito de perspetivar possíveis narrativas de hetero-exclusão. Consideramos assim que este tópico

\footnotetext{
${ }^{15}$ Este é um projeto de intervenção social e artística, que após o sucesso no Bairro do Cerco, foi alargado para outros bairros sociais tidos como problemáticos no Porto, tais como o Bairro de Ramalde, da Pasteleira e de Lordelo do Ouro. O projeto consistia no incentivo da criação artística por parte dos jovens moradores do Bairro do Cerco que como verificamos durante as entrevistas exploratórias e informais, em 2017 - já tinham um background no mundo do hip-hop. Para o efeito, o programa Cultura em Expansão contou com a presença de artistas de renome nacional, tais como a Capicua e o André Tentugal, e ainda possibilitou a atuação do grupo em grandes salas na cidade do Porto, como por exemplo o Teatro Sá da Bandeira. O programa durou sensivelmente um ano, produziram um álbum e quando o mesmo terminou - os jovens ficaram sem apoios novamente. No decorrer das nossas conversas informais, alguns dos membros referem que se sentiram usados, mas que decidiram transformar aquele projeto OUPA! num centro comunitário, visto que perderam o acesso a equipamentos, a estúdios e outro tipo de ajudas por parte da Câmara Municipal do Porto. Em 2018, o estúdio/ centro comunitário ainda se encontrava em processo de construção, tendo apenas uma sala minúscula para as gravações.

${ }^{16}$ Um Jornal de referência português quando se trata de notícias sobre atividades ou intervenções artísticas.
} 
é um excelente ponto de partida para a análise e aproximação aos lugares/contextos em questão. Assim no âmbito das cinquenta e sete notícias que recolhemos sobre o Bairro do Cerco do Porto, as notícias breves ${ }^{17}$ são aquelas que menor destaque possuem, por oposição às notícias pequenas e de dimensão média (entre uma a duas páginas), o que nos fez desde logo questionar a simbologia e o peso das temáticas aquando da sua associação ao bairro. Então, visto que consideramos os discursos midiáticos como uma forma de dizer sobre a sociedade, procedemos à criação de um conjunto de categorias analíticas, que de certo modo abrangem diferentes esferas da do Bairro, ao mesmo tempo em que procuramos estabelecer algumas ligações com o tamanho das notícias, por exemplo, importa compreender se as notícias que relatam a temática da violência possuem maior ou menor dimensão em comparação às notícias que abordam temáticas culturais e sociais, vejamos o seguinte gráfico:

Gráfico 1 Análise das notícias sobre o Bairro do Cerco (de 2012 a 2017) considerando a extensão da notícia e as categorias de análise (número)

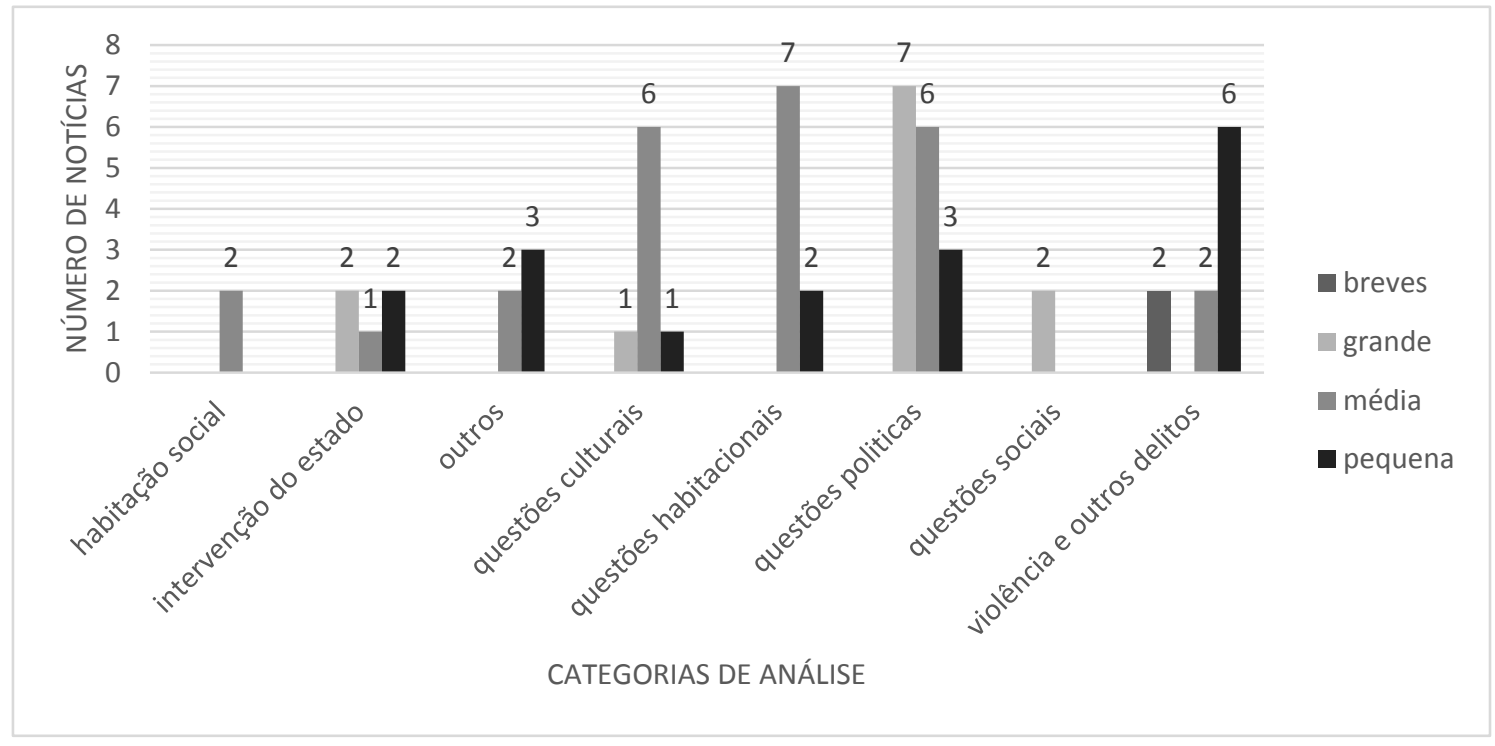

Fonte: Jornal Público, 2012 a 2017.

$\mathrm{Na}$ análise deste gráfico, conseguimos destacar algumas ideias essenciais para a nossa discussão e abordagem analítica. Primeiramente, o fato de para a categoria relativa à habitação social, apenas encontrarmos a ela associadas notícias de dimensão média, e por outro lado quando viramos o nosso olhar para temáticas categorizadas

\footnotetext{
${ }^{17}$ Um tipo específico de conteúdo que é produzido no âmbito do jornal Público, que se caracteriza por ser a apresentação de notícias/conteúdos que apenas possuem um ou dois parágrafos no máximo.
} 
como sendo inerentes à intervenção Estatal, tais como a referência a questões políticas e sociais, é aqui que surgem as notícias de maior dimensão, perfazendo um total de onze. Por fim, contrariando o senso comum alusivo a discursos mediáticos referentes ao Bairro do Cerco e à relação deste espaço com temáticas como a violência e outro tipo de delitos ou conflitos, conseguimos perspectivar que esta temática encontra-se presente de diversas formas, desde notícias pequenas, breves e médias.

Para outras categorias de análise, podemos encontrar e assumir discrepâncias, como é o caso das questões culturais, porém o fato de na temática da violência e outros delitos as breves estarem igualadas às médias levanta algumas questões, nomeadamente ao nível das breves - para o Bairro do Cerco - no sentido em que estas estão sempre associadas à criminalidade. Será que, apesar da pequena dimensão e simbologia no âmbito no Jornal como um todo, este fator contribui de certo modo para a perpetuação dos sentimentos de medo, insegurança e estigma? Será que a mensagem negativa, ainda que numa pequena dimensão, predomina em face de uma mensagem positiva transmitida em notícias de grande extensão? Devido a estas inquietações, achamos pertinente compreender como se processam estas temáticas/ categorias de análise de acordo com os anos de recolha da informação, também com o intuito de obter uma perspectiva temporal dos discursos acerca do bairro,

Gráfico 2 Frequência das categorias de análise de acordo com o ano de edição do Jornal Público, entre 2012 e 2017

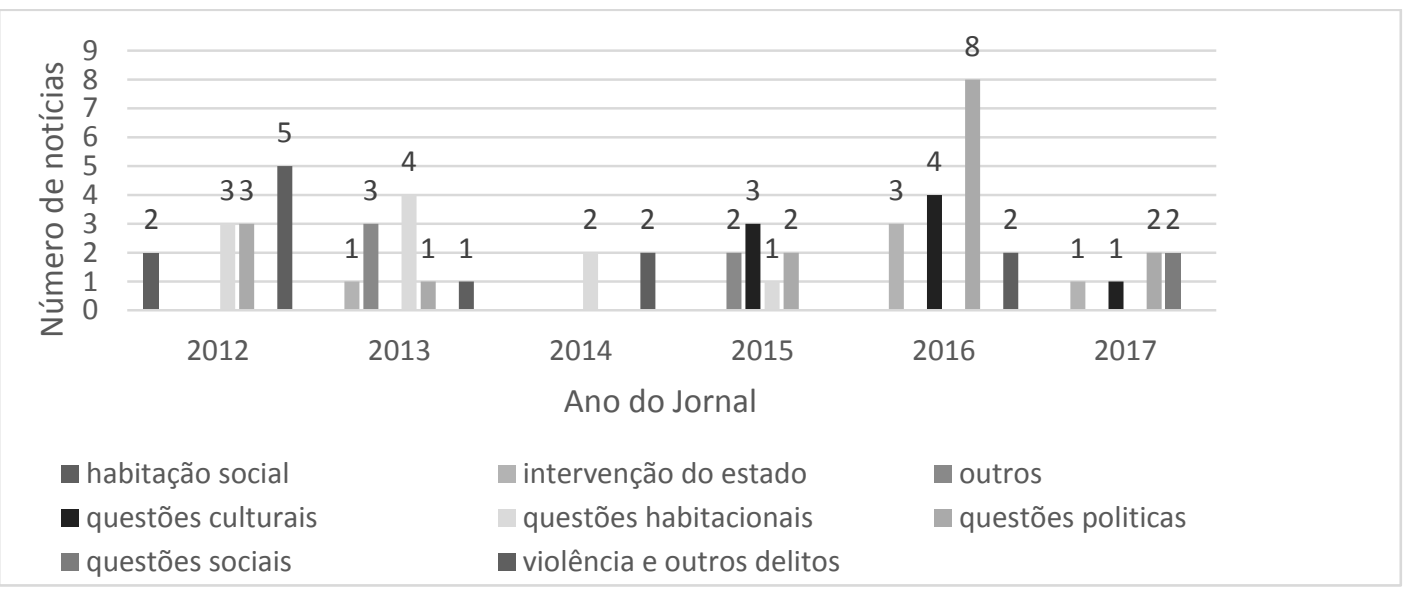

Fonte: Jornal Público, 2012 a 2017.

Desde logo devemos destacar as questões políticas no contexto geral do Jornal Público, isto é, de 2012 a 2015 poucas ou praticamente nenhuma notícia foi escrita 
tendo como conteúdo a dimensão política, porém em 2016 (ano em que foi eleito o Presidente da República) houve um aumento exponencial das mesmas, principalmente pelo facto deste ter feito uma visita ao Bairro do Cerco do Porto ${ }^{18}$, motivo esse que causou um impacto no mundo político e social talvez por ter sido um ato inédito que ainda hoje marca os indivíduos residentes no bairro, “(...) mas o chefe do Estado, como que em modo de campanha eleitoral, não se furtou a beijos e abraços aos moradores do bairro, enquanto se dirigia ao Largo dos Afectos, onde um palco anunciava a exibição de um grupo rap.” (Margarida Gomes, "Marcelo canta o rap dos afectos” in Público, 12 de março de 2016).

Dentro das questões culturais, conteúdo inexistente em relação ao Bairro do Cerco nos anos de 2012, 2013 e 2014, estas obtiveram um crescimento desde 2015 até 2017, muito em parte com os incentivos económicos e sociais da Câmara Municipal do Porto, do projeto de intervenção social e artística OUPA!Cerco, “(...) Oupa! No palco secundário, novíssimo projeto de hip-hop que nasceu numa residência artística no Bairro do Cerco com oito jovens, numa iniciativa da Câmara Municipal do Porto (...)" (Mariana Duarte, "O charme de John Legend num Marés Vivas superlotado" in Público, 18 de julho de 2015).

De grosso modo conseguimos apurar alguns dos padrões de publicação de notícias de acordo com algumas temáticas ou categorias consideradas por nós relevantes, sendo este um fator de compreensão dos discursos que predominam ou se associam a este espaço físico em questão que está a ser alvo de análise. Mais ainda, a maior incidência de notícias sobre a violência e/ou criminalidade referentes ao Cerco deu-se em 2012. Apesar de as mesmas não serem num número elevado, este tipo de conteúdos transparece em praticamente todos os anos de recolha, com exceção de 2015 e de 2017. Além disso, os conteúdos faziam frequentemente referência ao consumo, à apreensão e à venda de drogas. É tão mais claro que estes discursos, repetidos com frequência ao longo de um período de tempo, começam a ser alvo de interiorização por parte das populações, conferindo classificações ao espaço e fomentando sentimentos de insegurança.

Para a observação desses processos decorrentes da vida na metrópole, recorremos a uma etnografia de rua, nos moldes propostos pelas antropólogas Ana

\footnotetext{
${ }^{18}$ Este aspeto ainda é um fator relevante e impactante na vida dos moradores do Bairro, visto que este foi o primeiro Presidente a visitar o Bairro. Esta visita, bem como a atuação do grupo OUPA! Cerco conferiu um sentimento de esperança na população, face a possíveis intervenções no espaço.
} 
Luiza Carvalho da Rocha e Cornelia Eckert (2013), as quais enfatizam como a pesquisa de campo é concretizada na cidade, por meio de caminhadas atentas, e da constante presença do etnógrafo no espaço da rua, compartilhando de um tempo vivido com os habitantes, e consecutivamente, desvendando os saberes e fazeres dos moradores da cidade. Para este tipo de exercício, o uso do diário de campo é indispensável, visto que foi através do mesmo que nós - enquanto investigadoras - conseguimos ver expressos os nossos sentimentos, associados a determinadas zonas do bairro, ao mesmo tempo que identificamos alguns dos sentimentos e sensações referidos em contexto de entrevista/conversa informal dos residentes desse bairro.

Atendendo aos discursos dos meios de comunicação social e à etnografia de rua, foi possível estabelecer a primeira ligação com o Bairro, no sentido em que procuramos olhar e ver os quotidianos que se entrelaçam no tempo, no fluxo contínuo dos acontecimentos atentemos ao seguinte mapa:

\section{Figura 5 Síntese das representações dos sentimentos de insegurança no Bairro do Cerco, em 2018}

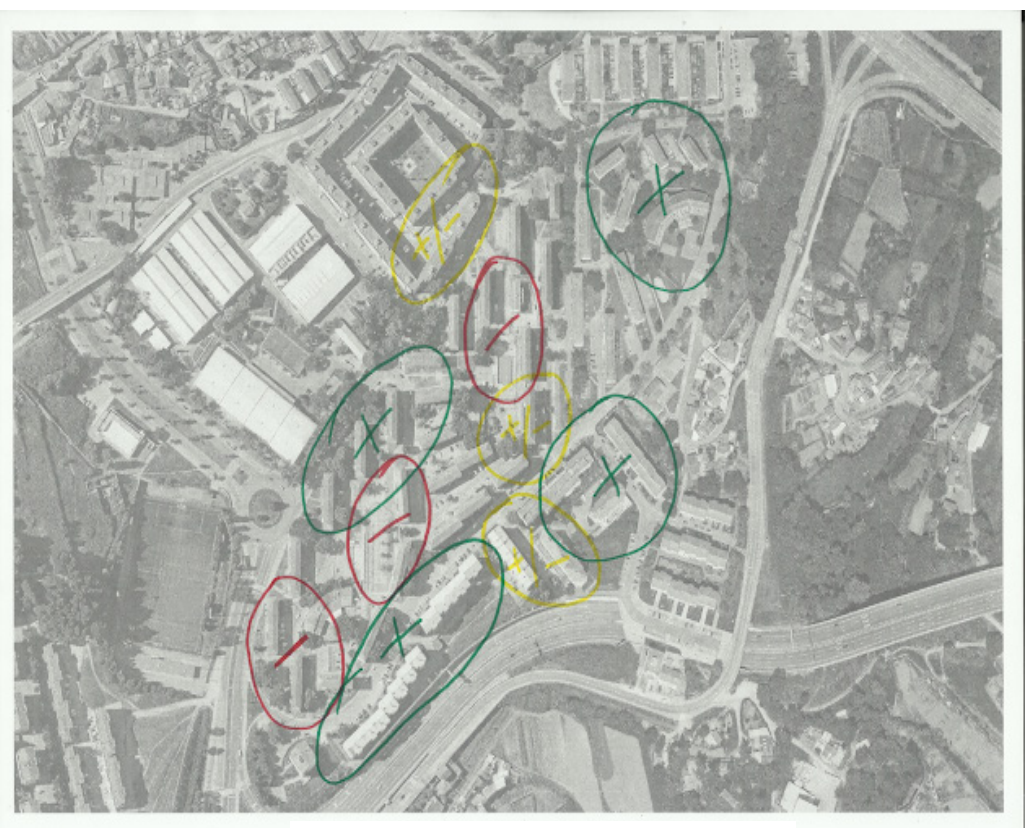

Fonte: Sousa (2018).

Este mapa que aqui apresentamos veio testar alguns limites, no sentido em que não é de todo um processo rápido como transparece por vezes, é preciso uma maturação dos dados e uma forte reflexão acerca deles mesmos para depois ser possível assinalar aquilo que se verificou, em jeito sintetizador. Uma das motivações para a elaboração deste mapa prendeu-se com a vontade de o leitor conseguir perspectivar aquilo que o 
investigador também sentiu, sendo que naquele momento também ele estava a sentir e a fazer parte do espaço físico e social. A verde $(+)$ encontram-se as áreas em que nos sentimos completamente à vontade, desinibidos e sem nenhum tipo de sentimento de insegurança, estas encontram-se por sua vez próximas ou até nos mesmos locais em que se observou um maior número de mulheres. Nos extremos do bairro encontra-se as áreas amarelas (+/-) onde se sentia algum desconforto, algo que advinha dos olhares das pessoas nas janelas, nas ruas e nos carros que passavam e viam uma cara desconhecida. A vermelho (-) assinalamos as áreas em que sentimos um maior sentimento de insegurança, por um lado pela concentração de indivíduos em determinados espaços, nomeadamente no café, na praça, no ringue e na antiga Associação do Futebol Clube do Porto, tendo sido nestes locais que se verificava uma maior proeminência do consumo e venda de substância psicoativas. O que queremos no fundo demonstrar é a elasticidade que os territórios possuem, pois existem áreas com sentimentos de segurança a ela associadas que se difundem e cruzam com áreas menos seguras (a vermelho e amarelo), algo que pode acontecer até pela própria morfologia dos blocos habitacionais, sendo circular, com inúmeros cantos, curvas e especificidades, bem como diferentes tipos de serviços e formas de usufruição dos espaços. Atentemos ainda a alguns discursos sobre os sentimentos de (in)segurança, a título exemplificativo, por parte dos residentes do Bairro do Cerco do Porto,

Eu lá está...se pensar nisso sinto-me pouco segura mas como habitualmente não penso nisso, nem estou a prever nada, nem meto em confusão...se pensar nisso, tenho receio realmente porque já nos assaltaram aqui e a polícia não fez nada...sabem quem são e não fazem nada. (Entrevista 3, Cerco do Porto)

Eu acho que não me fariam nada, mas também me conhecem daqui mas as pessoas que vêm trabalhar não têm grandes problemas...mas também já houve alturas que era diferente e havia pessoas que moravam aqui...agora estão presas também não é...mas já violaram uma rapariguinha ali naquela parte de onde eu vinha... (Entrevista 1, Cerco do Porto)

Ainda quanto aos discursos mediáticos, a maioria dos residentes do bairro com quem falamos referiu que concordava que os meios de comunicação social contribuíam para a perpetuação dos sentimentos de insegurança face ao bairro.

O que ontem podia ter sido apenas um dia de aulas normal, acabou afinal com uma professora agredida na escola básica e secundária do Cerco do Porto, em Campanhã. (Pedro Sales Dias, "Professora agredida numa escola onde dezenas de pais acorreram devido a falso caso de ébola", in Público, 22 de outubro de 2014)

A PSP deteve 14 pessoas na sequência de 51 buscas domiciliárias realizada ontem e anteontem nos bairros de Francos, Aleixo, Ramalde, Pasteleira e Cerco, no Porto. No conjunto dos dois dias, a polícia apreendeu estupefacientes, dinheiro e veículos num valor estimado de 1,5 milhões de euros. (Alexandra João Martins, "PSP 
apreende mais de 8KG de cocaína no Porto", in Público, 7 de março de 2013)

Estes discursos permitem que seja estabelecida uma ponte com os sentimentos de segregação, com o estigma e com a exclusão de indivíduos exteriores ao bairro. Pretendíamos através das entrevistas, das conversas informais e até mesmo através das incursões que eram feitas, perceber até que ponto as opiniões de quem não vive no bairro interferem com os modos de vida, com os sentimentos e com as histórias dos moradores do Bairro do Cerco do Porto. Um dos principais pontos em que estes sentimentos e possíveis constrangimentos surgiam e se assumiam como essenciais, encontravam-se inseridos na problemática do mercado de trabalho.

As representações do bairro pelo outro, também se relacionam e convivem com a exclusão social e seus processos de vivência ao nível dos discursos e pensamentos dos residentes do Bairro do Cerco. O bairro ainda permanece um lugar estigmatizado e excluído por quem não vive lá, o que nos permite estabelecer uma relação com aquilo que Levitas (1998) afirma no que diz respeito à divisão dos indivíduos em dois grupos, pois os excluídos são os moradores do bairro do Cerco e os restantes os não moradores e, muitas vezes, portadores do estigma. Estes sentimentos contribuem e apresentam um impacto nas histórias e nos modos de vida dos atores sociais, pois estes ainda se sentem estigmatizados, oprimidos e, acima de tudo, conscientes de que este preconceito permanece de forma vincada no imaginário da população portuguesa. Então, talvez devido ao fato de sentirem e presenciarem o estigma face aos bairros, o que a nosso ver poderá contribuir para a construção de uma identidade coletiva forte, uma fomentação sustentada ao longo do tempo da e na importância de inserção numa comunidade, aspeto este que irá ser analisado de seguida. Os discursos de afetação das identidades individuais e coletivas, vindos do exterior do Bairro do Cerco, começam a ter um impacto a outro nível nos moradores, no sentido em que estes mesmos passam a ser interiorizados e reproduzidos pelos mesmos, ou seja, eles próprios estabelecem diferenças, muito acentuadas, entre quem vive no bairro versus quem não vive ou até mesmo em outros locais da cidade.

No caso da Grande Cruzeiro, a região tem sido constantemente retratada como "perigosa", um território valorado negativamente no contexto urbano da cidade de Porto Alegre e onde a modelização, principalmente dos jovens que ali residem, gira em torno da violência. Quando a Grande Cruzeiro não é retratada pela mídia como local perigoso e violento, aparece como expressão de abandono e exclusão social, com promessas de 
investimentos ou espaço de luta em prol de sua urbanização. Ao iniciar pesquisa na Região, em 2014, nos deparamos com uma grande quantidade de notícias produzidas pela mídia local, tais como: "Vila Cruzeiro em pé de guerra na Zona Sul de Porto Alegre”, “Após confronto, BM vai intensificar efetivo na Vila Cruzeiro do Sul”, ou ainda, "Quatro pessoas são presas por tráfico de drogas, na Vila Cruzeiro do Sul, em Porto Alegre".

A mídia local dá espaço significativo aos comportamentos agressivos, em especial dos jovens da Grande Cruzeiro. Conforme Diógenes (1998: 164), “a mídia não apenas alardeia a presença das gangues na cidade, como também cria estereótipos, reforçando o estigma da população em relação aos jovens pobres da periferia". Essa perspectiva que direciona as reportagens da mídia local é que ressoa na política do medo e justifica ações de repressão por parte da polícia e que são vivenciadas pelos moradores da Grande Cruzeiro.

Na reportagem publicada no Jornal Zero Hora, do dia 20/10/2015, intitulada “Crime e medo no morro", a Região é retratada como um local assustador desde os anos 1850, quando ainda era mata fechada e considerada um local de emboscada para quem ali se arriscava a escalar o morro. A reportagem refere que passados quase dois séculos subir àquela área é tão perigos quanto naqueles tempos, só que os motivos são outros: “fulminada pela explosão demográfica desordenada que se espalhou a criminalidade, uma das mais belas paisagens de Porto Alegre, onde o sol ilumina o Guaíba beijando as curvas da cidade, perdeu o encantamento" (Zero Hora, 20/10/2015). A reportagem avança ainda para o abandono do poder público em relação à Região e a apropriação pelo tráfico de drogas nas três últimas décadas. 
Figura 6- Reportagem Jornal Zero Hora 20/10/2015

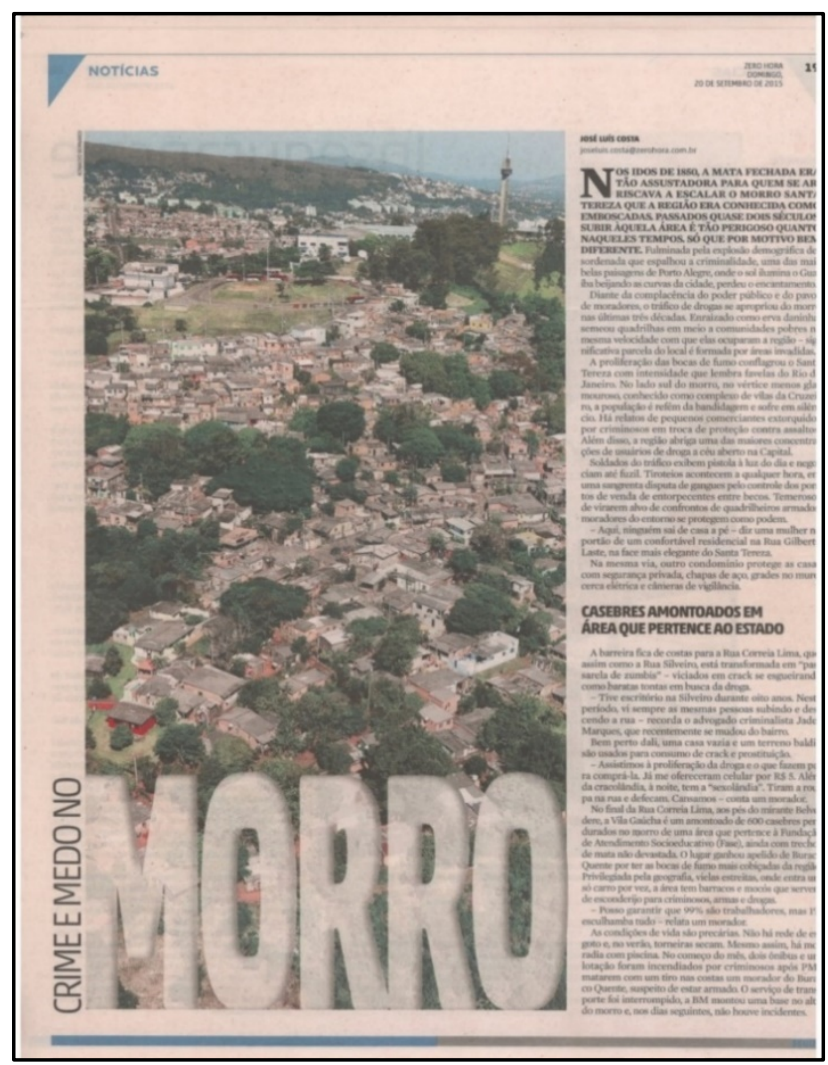

Fonte: Jornal Zero Hora.

Em outra reportagem do mesmo jornal, datada de 25/04/2014, denominada "Território em Guerra - Cruzeiro dominada pelo medo" a Região é retratada como uma das mais violentas da cidade, com uma taxa de 47,45 de homicídio por 100 mil habitantes, sendo que na cidade o índice é de $33,1 \%$. 
Figura 7 - Reportagem Jornal Zero Hora 25/04/2014

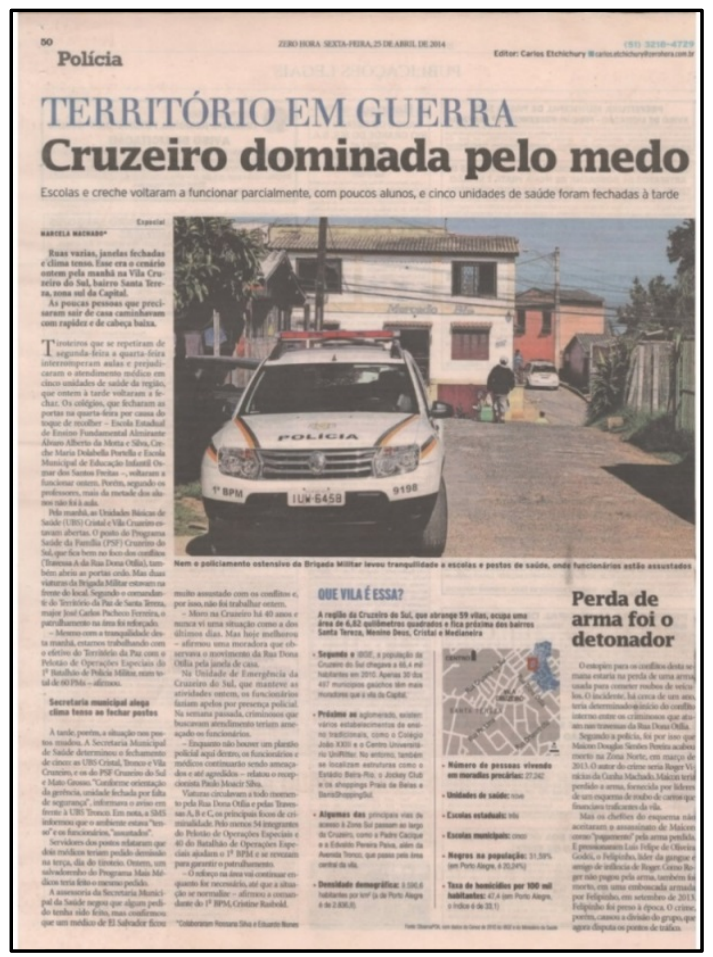

Fonte: Jornal Zero Hora.

As narrativas dos interlocutores contribuem para essa compreensão:

Quando falam na TV, no jornal, falam e violência e de tudo que é ruim. Isso não é verdade. Aqui não é uma Região de vagabundos e ladrões. Ela foi formada por trabalhadores. Agora tem o tráfico, mas essa não pode ser a única imagem da Região (Entrevista com Interlocutor 1 - Grande Cruzeiro).

Aqui é uma vila de pessoas de bem, de famílias, com crianças e trabalhadores. Quando se fala na Cruzeiro se fala em miséria, em marginalidade, em violência, em bandido e vagabundo, em tudo de pior que se possa imaginar (Entrevista com Interlocutor 4 - Grande Cruzeiro).

A discussão sobre a violência e criminalidade ganha amplitude, quando associada às condições das camadas mais pobres dos centros periféricos do país (Wacquant, 2001). As imagens retratadas pela mídia, tais como delinquentes, marginais, bandidos, indolentes, bárbaros, são atreladas a imagens que caracterizam a paisagem dos contextos onde habitam, tais como favelas, vilas, malocas, invasões, bairros, entre outras. Assim, são construídas categorias simbólicas que atingem um enorme contingente de pessoas, outorgando-lhes atributos que são reconhecidos socialmente e 
que lhes conferem uma identidade social caracterizando a sua condição e seus espaços de moradia. (Barbosa, 2013).

A mídia local, espaço significativo aos comportamentos agressivos dos jovens da Grande Cruzeiro. Conforme Diógenes (1998: 164), “a mídia não apenas alardeia a presença das gangues na cidade, como também cria estereótipos, reforçando o estigma da população em relação aos jovens pobres da periferia”. Essa perspetiva que direciona as reportagens da mídia local, que ressoa na política do medo e que justifica ações de repressão por parte da polícia e que são vivenciadas pelos moradores da Grande Cruzeiro.

Coletar as notícias sobre os jovens foi uma experiência dolorida, em especial porque as reportagens apresentavam jovens mortos, baleados, esfaqueados, balas perdidas, toque de recolher.

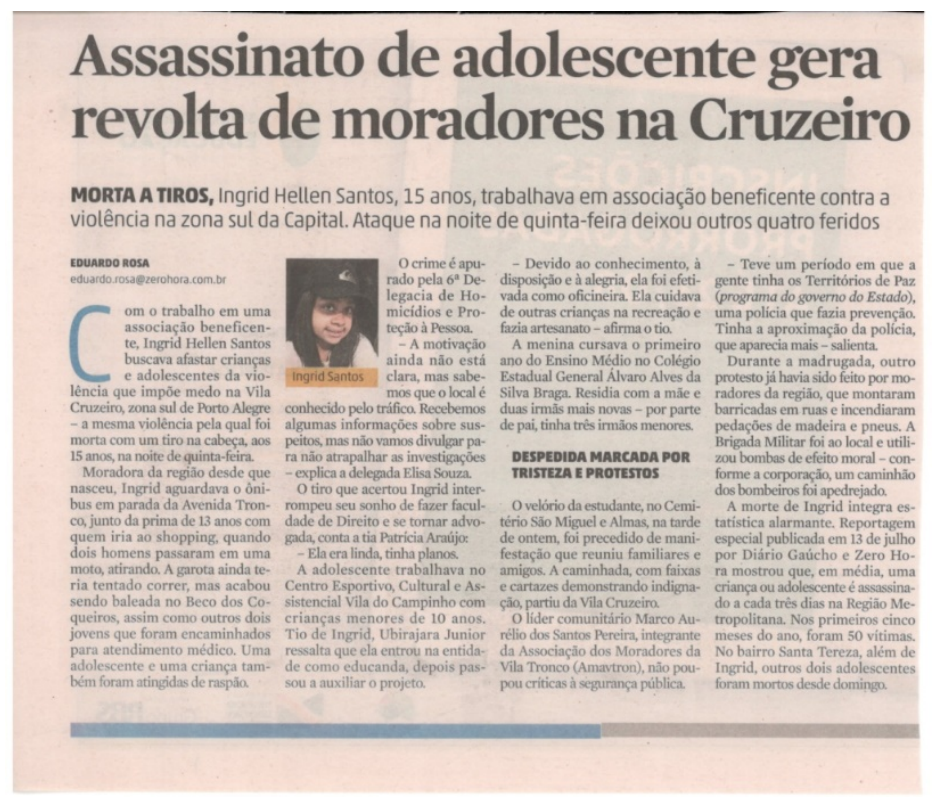

Fonte: Jornal Zero Hora. 
Figura 9 - Reportagem Jornal Zero Hora 25/04/2017

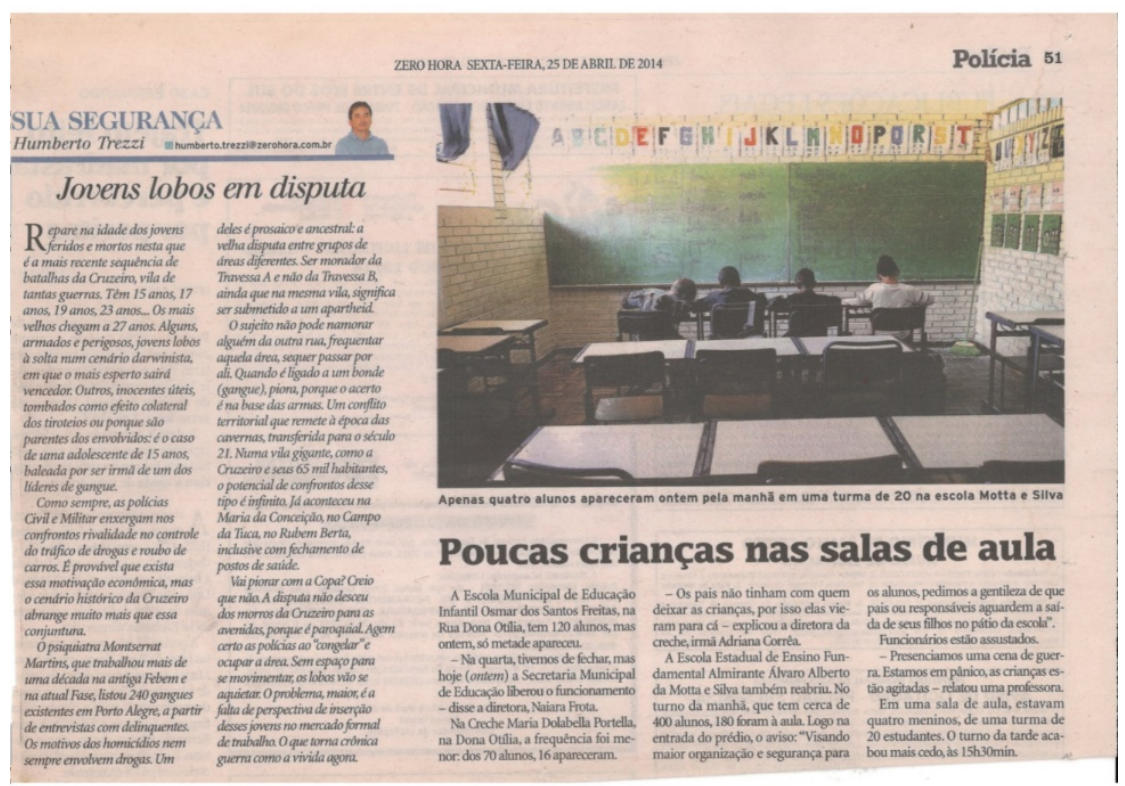

Fonte: Jornal Zero Hora.

Figura 10 - Reportagem Jornal Zero Hora 25/04/2017

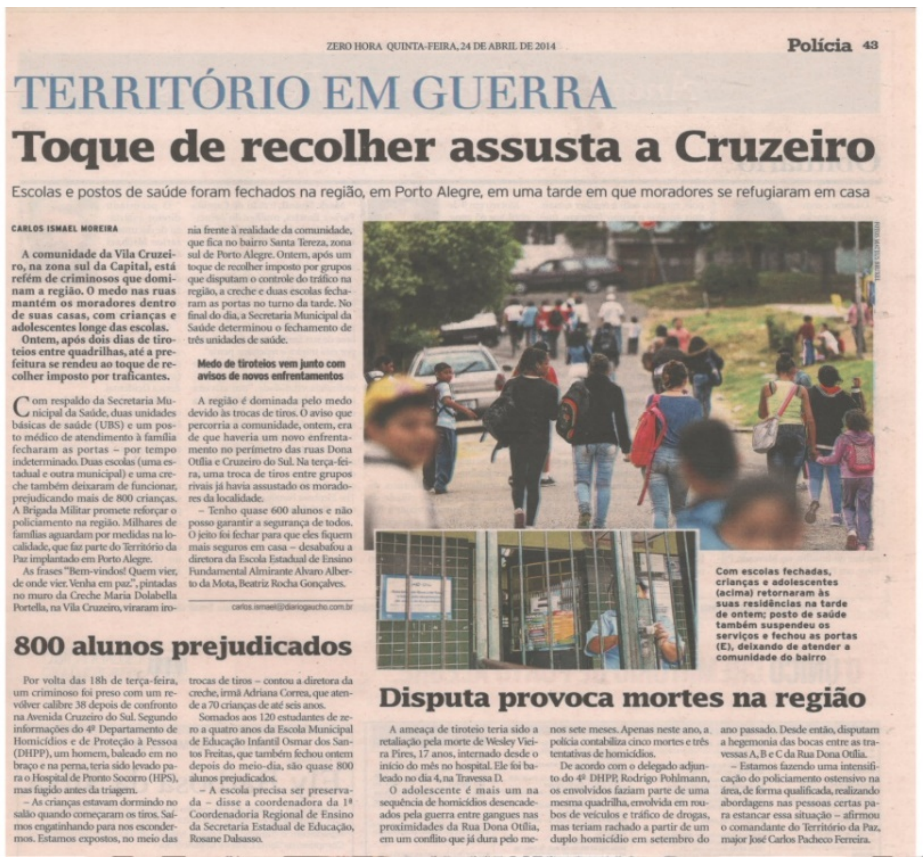

Fonte: Jornal Zero Hora.

Em diferentes reportagens, as falas autorizadas sobre a Grande Cruzeiro noticiam o "rosto" violento da Região, contribuindo para que paire sobre o território os 
estigmas (Goffmann, 1982) decorrentes desta representação social. Ao reafirmar a territorialização da pobreza ali historicamente promovida, se reforça ainda mais as figurações sociais estigmatizantes que pesam sobre a Região. Morar na Grande Cruzeiro, assim como no Bairro do Cerco, significa lidar com o preconceito. Nada mais se registra além das imagens congeladas de demarcam esses territórios e suas populações. A narrativa produzida pela imprensa delimitou um lugar, um espaço social para significar novos personagens. De lá para cá algo ficou entre o mito, os símbolos, entre a cidade real e a cidade imaginada (Ávila; Araújo, 2006).

Morar na Grande Cruzeiro ou no Bairro do Cerco implica carregar sobre si esse legado que é manifesto no ethos desses territórios. Enquanto essas regiões são retratadas nas páginas de jornal e nos noticiários de televisão como sendo violentas e perigosas, a cidade esquece que ali vivem pessoas que se consideram felizes, que tem orgulho do lugar onde moram, e que lutam para sobreviver em meio ao descaso das autoridades e ao preconceito da população. $\mathrm{Na}$ Grande Cruzeiro e no Bairro do Cerco se encontram indivíduos que embora lidem com significativas restrições financeiras, com carência de alimentos, com moradias precárias, há também uma história de personagens, que apesar da precariedade onde vivem, lutam para sobreviver.

Com certeza, a Grande Cruzeiro e o Bairro do Cerco, como local de residência de algumas das camadas mais pobres da população são lugares onde o Estado não se instalou de fato e em que precisa ser ativada a qualidade de todos os serviços para evitar o medo, a escuridão, o lixo largado, a insegurança, a ilegalidade (Meirelles \& Athayde, 2014). São territórios ainda pouco explorados do ponto de vista da cidadania e da memória. A desigualdade de acesso a direitos básicos, inerentes à noção de cidadania, representam a continuidade e o paradoxo dessa sociedade que, ao mesmo tempo em que cultiva os valores da independência, da autonomia e da igualdade, presentes na lógica do indivíduo-cidadão (Cardoso de Oliveira, 1992), reproduz permanentemente segmentações e diferenciações hierárquicas. As reportagens coletadas no âmbito das pesquisas realizadas na Grande Cruzeiro e no Bairro do Cerco demonstram a pluralidade de pontos de vista, pois, ao falarem do que é viver nestes territórios, falam ainda mais do que é viver em certas condições históricas e sociais concretas, carregadas de materialidade, que perduram no tempo. Os moradores das camadas mais pobres da população, como os que encontramos na Grande Cruzeiro e no Bairro do Cerco, vivem os dilemas da sua condição territorial, com as possibilidades e limites que são historica, 
social e politicamente produzidos. Residem e constroem as suas identidades em espaços sociais de precarização da cidadania. A pobreza, as adversidades e ausências estruturais que impactam na qualidade de vida compõem os principais elementos que eles enfrentam ao longo do tempo, daí que ainda se assuma como premente um olhar atento que vise a compreensão de todos estes processos que são compostos por continuidades e descontinuidades, em diversos níveis da vida social.

\section{Considerações Finais}

As aproximações com a Grande Cruzeiro e com o Bairro do Cerco, a partir das pesquisas que desenvolvemos nestes territórios, revelou-nos um sentido secreto dessas regiões, denotando o que a cidade pensa em relação às pessoas que ali residem, às diferenças que se expressam na própria cidade, demarcando fronteiras internas, com forte dimensão segregativa (Foote-whyte, 2005; Park, 1987). Cada vez mais se criam distâncias reais e simbólicas entre os moradores das cidades. Há um muro simbólico que a cidade ergueu e que constantemente é refeito, por força das representações sociais. As caminhadas pelos territórios da Grande Cruzeiro e do Bairro do Cerco, inspiradas em uma etnografia de rua (Rocha \& Eckert, 2013) constituíram-se num caminho inicial para remontar às memórias da paisagem urbana das duas regiões e compreender as formas de interação social tecidas nas particularidades de se habitar esses territórios das cidades de Porto Alegre e do Porto.

A partir das pesquisas realizadas na região da Grande Cruzeiro e no Bairro do Cerco foi possível refletir sobre as constantes situações de riscos e violências que se expressam nas metrópoles contemporâneas.. As grandes cidades tem se apresentado como a expressão mais aguda e complexa dessa problemática, em que se misturam riqueza, desigualdade, progresso tecnológico, analfabetismo, desemprego, ressentimento, tensão social e conflitos de toda ordem. Certamente o panorama não é homogêneo e as situações são altamente diferenciadas, em função de histórias e características das sociedades e áreas culturais específicas (Velho, 2004), como no caso de Porto Alegre e de Porto.

Contudo, mesmo apesar da sua heterogeneidade - quer pela cidade, quer pelo 
país ou mesmo até pela diferença entre bairro e favela - continuamos a ver presente nestes territórios o peso das cargas simbólicas prejorativas que se encontram associadas às populações que residem e que habitam estes espaços desterritorializados (Haesbaert, 2004, 2005) e excluídos. Porém, esses constrangimentos - apesar de serem um fator contributivo para processos segregacionais e para a fragmentação das identidades fomentam a importância da memória, dos sonhos, incentivam e fortalecem as relações de vizinhança e, essencialmente, criam comunidades que resistem ao longo do tempo e em conjunto.

\section{REFERÊNCIAS}

ÁVILA, Fátima; ARAÚJO, Jeferson R. Vilas da grande cruzeiro (Memória dos bairros, 17). Porto Alegre: Unidade Editoral/SMC, 2006.

BARBOSA, Ana P. Entre sociabilidades e representações sociais: uma experiência etnográfica na Vila Cruzeiro do Sul, Porto Alegre. Iluminuras, Porto Alegre, v. 16, n. 38, p.165-180, jan./jul. 2015.

BARBOSA, Ana P. Sobre juventudes e territorialidades: estudo etnográfico das trajetórias juvenis na Grande Cruzeiro, em Porto Alegre, RS. [Tese de Doutorado]. Programa de Pós-Graduação em Diversidade Cultural e Inclusão Social. Universidade FEEVALE, 2017.

BARBOSA, Ana P. Ecos do passado: DNA da situação irregular ressoando na proteção integral. [Dissertação de Mestrado]. Programa de Pós-Graduação em Diversidade Cultural e Inclusão Social. Universidade FEEVALE, 2013.

BOURDIEU, Pierre. The forms of capital, 1986. In SZEMAN, Imre \& KAPOSY, TIMOTHY. Cultural theory: An anthology. Hoboken, NJ: Wiley-Blackwell, 2010.

CALDEIRA, Teresa P.R.. A política dos outros. O cotidiano dos moradores da periferia e o que pensam do poder e dos poderosos. SP; Brasiliense, 1984. 
CARDOSO, Luis O.. Direitos humanos e cidadania no Brasil: algumas reflexões preliminares, Série Antropologia, 122. Brasília: UnB/Departamento de Antropologia. 1992.

DE CERTEAU, Michel. A invenção do cotidiano. Petrópolis, RJ: Vozes, 2012.

DIAS, Pedro S. Professora agredida numa escola onde dezenas de pais acorreram devido a falso caso de ébola. Jornal Público. Número de série 8959. 12 de outubro, 2014. Disponível em: https://www.publico.pt/jornal

DUARTE, Mariana. O charme de John Legend num Marés vivas superlotado. Jornal Público. Número de série 9225. Julho, 27, 2015. Disponível em: https://www.publico.pt/jornal

ECKERT, Cornelia; ROCHA, Ana L. C. Premissas para o estudo da memória coletiva no mundo urbano contemporâneo sob a ótica dos itinerários urbanos e suas formas de sociabilidade. Iluminuras: Série do Banco de Imagens e Efeitos Visuais, Vol. 2, no 4. Porto Alegre: Banco de Imagens e Efeitos Visuais, PPGAS/UFRGS, 2001.

ECKERT, Cornelia; ROCHA, Ana L. C. Etnografia de rua: estudos de antropologia urbana. Porto Alegre: Editora da UFRGS, 2013.

ECKERT, Cornelia; ROCHA, Ana L. C. O tempo e a cidade. Porto Alegre: Editora da UFRGS, 2005.

ECKERT, Cornelia; LORD, Lúcio. Nascidos na beira do trilho: um estudo antropológico na vila dos ferroviários/Porto Alegre. Iluminuras Revista Eletrônica do BIEV/PPGAS/UFRGS, 2015.

FOOTE-WHYTE, William. Sociedade de Esquina. Rio de Janeiro: Jorge Zahar, 2005.

FRÚGOLI JR., Heitor. O urbano em questão na antropologia: interfaces com a sociologia. Revista de antropologia. São Paulo: USP, 2005. v 48, $\mathrm{n}^{\circ} 1$.

GOMES, Margarida. Marcelo canta o rap dos afectos. Jornal Público. Número de série 9461. Março, 8, 2016. Disponível em: https://www.publico.pt/jornal

GUERRA, Paula (2012). Da exclusão social à inclusão social: eixos de uma mudança paradigmática. Revista Angolana de Sociologia, N. ${ }^{\circ}$ 10, 91-110.

GUERRA, Paula. A cidade na encruzilhada do urbano. Algumas modalidades de relação e um estudo de caso acerca do processo de recomposição espacial e social do 
tecido urbano portuense na década de 90. Porto: Faculdade de Letras da Universidade do Porto, 2002. Dissertação de Provas de Capacidade Científica e Aptidão Pedagógica (equivalente a dissertação de mestrado) em Sociologia urbana. URL: http://paulaguerra.pt/arquivo/247

HAESBAERT, Rogério. O mito da desterritorialização: do "fim dos territórios" à multi-territorialidade. Rio de Janeiro: Bertrand Brasil, 2004.

HAESBAERT, Rogério. Da desterritorialização à multiterritorialidade. Anais X Encontro de Geógrafos da América Latina, Universidade de São Paulo, 2005.

HARVEY, David. A condição pós-moderna. São Paulo: Loyola, 1989.

IBGE, 2000. Censo Demográfico de 2000. Fundação Instituto Brasileiro de Geografia e Estatística, dados referentes ao município de Porto Alegre, fornecidos em meio eletrônico.

IBGE, 2010. Censo Demográfico de 2010. Fundação Instituto Brasileiro de Geografia e Estatística, dados referentes ao município de Porto Alegre, fornecidos em meio eletrônico.

LEVITAS, Ruth. The inclusive Society: social Exclusion and New Labour. London: Macmillian, 1998.

MAGNANI, José G. C.. Quando o campo é a cidade: fazendo antropologia na metrópole. Textos de antropologia urbana. São Paulo: EDUSP, 1996.

MAGNANI, José G. C. Da periferia ao centro: trajetórias de pesquisas em antropologia urbana. São Paulo: Editora Terceiro Nome, 2012.

MAGNANI, José G. C. (Org.); SOUZA, Bruna M. (Org.). Jovens na Metrópole: etnografias de circuito de lazer, encontro e sociabilidade. São Paulo: Ed. Terceiro Nome, 2007.

MARCUS, George E. Ethnography in/of the World System: The Emergency of MultiSited Ethnography. In: George E. Marcus. Ethnography through Thick/Thin. Princeton: Princeton University Press, 1998.

MARTINS, Alexandra J. PSP apreende mais de $8 \mathrm{~kg}$ de cocaína no Porto. Jornal Público, Número de série 8366. 20 de março, 2013. Disponível em: https://www.publico.pt/jornal 
MEIRELLES, Renato; ATHAYDE, Celso. Um país chamado favela: a maior pesquisa já feita sobre favela brasileira. São Paulo: Edita Gente, 2014.

NORBERG-SCHULZ, Christian. Existencia, Espacio y Arquitectura. Barcelona: Editorial Blume, 1974.

PARK, Robert E. A cidade: sugestões para a investigação do comportamento humano no meio urbano. In VELHO, Otávio G. (org.). 4 ed. O fenômeno urbano. Rio de Janeiro: Guanabara, 1987.

POCHMANN, M.; AMORIM, R. (Orgs). Atlas da exclusão social no Brasil. São Paulo: Cortez, 2003.

QUEIRÓS, João. No Centro à margem. Sociologia das intervenções urbanistícias e habitacionais do Estado no centro histórico do Porto. Tese de doutoramento em Sociologia, 2014. Porto: Faculdade de Letras da Universidade do Porto.

RÉMY, Jean. La Ville et L'Urbanisation. Gembloux, Dumlot, 1974.

ROCHA, Ana L.C. Antropologia das formas sensiveis: entre o visível e o invisível, a floração de símbolos. Porto Alegre, RS: Horizontes Antropológicos, Ano 1, n². 1995.

RODRIGUES, Ana F. \& ALMEIDA, Catarina. Reabilitação. 2019/2020. Disponível em: https://infomedia.atavist.com/bairro-do-cerco\#chapter-4602508

SIMMEL, Georg. A metrópole e a vida mental. In: VELHO, Otávio (Org). O fenômeno urbano. Rio de Janeiro, Editora Guanabara, 1987.

SOUSA, Sofia. O Cerco é a minha casa! Apropriações e identidades face ao espaço habitado. Dissertação (Mestrado), 2018, Porto: Faculdade de Letras da Universidade do Porto.

VELHO, Gilberto. A utopia urbana: um estudo de antropologia social. Rio de Janeiro: Zahar, 1989.

VELHO, Gilberto. Individualismo e cultura: notas para uma antropologia da sociedade contemporânea. Rio de Janeiro: Zahar, 2004.

VELHO, Otávio G. (Org). O fenômeno urbano. Rio de Janeiro, Zahar, 1979.

WACQUANT, Loïc J.D. Os condenados da cidade: Estudos sobre marginalidade avançada. Rio de Janeiro, Editora Revan. 2001. 
ZALUAR, Alba. Violência e criminalidade: saída para os excluídos ou desafio para a democracia?. In Sérgio Miceli (org.). O que ler para conhecer o Brasil, vol. I, São Paulo, Anpocs, 1999.

ZALUAR, Alba. A Máquina e a Revolta. As organizações populares e o significado da pobreza. São Paulo: Brasiliense, 1985.

ZALUAR, Alba. Um Século de Favela. Rio de Janeiro: Fundação Getúlio Vargas, 1998.

Recebido: $06 / 05 / 2020$

Aprovado: 04/09/2020 